\title{
Konlk MATA SEBAGAI SUMBER IDE PENCIPTAAN MOTIF DALAM BUSANA MODERN
}

Volume 2, Nomor 1 Januari 2020,

\section{Putri Utami Mukti}

Pascasarjana ISI Yogyakarta

Institut Seni Indonesia Yogyakarta

e-mail : putriutamimukti@gmail.com

\begin{abstract}
ABSTRAK
Mata adalah jendela jiwa dan jendela dunia ke dalam kehidupan, dengan semua peristiwa dapat dilihat dan dihargai itu memiliki bentuk estetika, filosofis konten dan nilai yang tinggi bagi kehidupan, maka dari itu menjadi penting untuk menyampaikan mata lewat media yang mudah diterima oleh masyarakat. Salah satu media yang dapat mewakili seluruh isi mata adalah seni kriya tekstil, karena memiliki turunan berupa busana yang menjadi kebutuhan utama bagi kehidupan manusia. Busana tidak hanya berfungsi sebagai pelindung tubuh tetapi bisa menjadi media komunikasi untuk menyampaikan pesan estetis. Mata akan digunakan sebagai sumber ide penciptaan motif dan diterapkan pada busana modern untuk menyampaikan konten makna dan filosofis yang terkandung di dalamnya dengan menggunakan pendekatan estetika dan ergonomi.
\end{abstract}

Kata kunci: Mata, busana, kriya tekstil

\begin{abstract}
The eyes are the Windows of the soul and the world's window into life, with all the events can be seen and appreciated it has a form of aesthetic, philosophical content and high value for life, therefore becomes essential to convey the eyes through the media that is easily accepted by the society. One of the media that can represent the entire contents of the eye is the art of textile craft, because it has a derivative form of clothing that became the main needs for human life. The clothes not only serves as a protector of the body but it can be a medium of communication to convey messages aesthetically. The eye will be used as the source of the idea of creation of motives and applied to the modern fashion to convey the philosophical meaning and content contained therein by using the approach to aesthetics and ergonomics.
\end{abstract}

Keyword: eyes, fashion, Craft textiles.

\section{PENDAHULUAN}

Mata adalah jendela hati, sekaligus jendela dunia, hampir seluruh keindahan dunia, yang sulit terucap dalam kata-kata dapat di bahasakan secara ringkas oleh mata. Bayangkan, jika kita mengajarkan lagu "Bintang kecil, dilangit yang biru" kepada tunanetra bawaan lahir, akan sangat panjang menjelaskan benda dan sifat dalam lagu itu. Karena mereka belum pernah melihat bintang, langit, pun warna biru itu seperti apa? Maka bersyukurlah orang-orang yang bisa melihat keindahan dunia yang tak dinikmati oleh orangorang tunanetra.

Banyak kata yang dipadankan dengan mata untuk merujuk pada keindahan, kasih sayang, cinta, semangat hidup, kebencian sekaligus kegenitan. Misalnya: "Cahaya mata-ku" kata lain untuk seseorang yang disayangi yang memberikan semangat hidup. "Cendera mata" memberikan sesuatu wujud perhatian, kasih sayang dan empati.
Demikian pula ada kata lainnya, yaitu "Mata hati" untuk menunjukkan kepekaan perasaan, "Matahari" sebagai salah satu "sebab" adanya kehidupan, dan istilah-istilah lainnya seperti mata duitan, mata keranjang, dan mata-mata lain.

Karya yang akan diciptakan perlu dipikirkan secara lebih mendasar dan menyeluruh sehingga perkembangan pembuatan karya tidak bertentangan dengan inti dari busana, desain busana modern didesain dengan mempertimbangkan estetis dan ergonomis. Busana modern memuat beberapa fungsi busana yang sangat penting, beberapa fungsi busana yaitu berfungsi untuk pelindung tubuh dan sebagai penutup tubuh selain itu busana berfungsi untuk memperindah penampilan. Motif yang akan dipadukan bentuknya ataupun diterapkan dalam busana adalah mata, mata dipilih sebagai inspirasi motif pada busana modern, yaitu stilisasi dari bentuk mata yang akan menjadi nilai tersendiri dan melekat pada busana modern. Mata mencerminkan 
jendela hati manusia, pemakaiannya sebagai motif merupakan realisasi kehidupan yang terekam oleh mata.

Mata memiliki banyak fungsi, selain sebagai media komunikasi juga mempunyai bentuk yang menarik. Bentuknya menarik terlihat dari tekstur dan warnanya, pengambilan ide mata kedalam bentuk busana modern karena dapat dipakai diberbagai acara. Konsep penciptaaan karya adalah mengkombinasikan model, teknik pengerjaannya menggunakan batik tulis, model busana mengacu pada bentuknya yang sedang berkembang pada saat ini.

\section{METODE PENELITIAN}

\section{Metode Pendekatan}

1. Pendekatan Ergonomi

Ergonomi digunakan sebagai metode pendekatan dalam pembuatan karya karena mengandung unsur faktor manusia yang dibutuhkan untuk pembuatan busana yang berkaitan dengan anatomi adalah bentuk, bentuk disini bentuk tubuh manusia menjadi hal dasar dalam pembuatan busana, kemudian psikologi adalah ketepatan dalam pemilihan warna yang tepat pada anatomi yang sesuai, dan fisiologi yaitu dari keseluruhan bentuk busana yang akan dibuat sehingga menciptakan kenyaman ketika dipakai.

2. Pendekatan Estetis

Dalam suatu penciptaan diperlukan pendekatan estetika yang mana ilmu yang memperlajari segala sesuatu yang berkaitan dengan keindahan, demikian penegasan Djelantik (2001: 7). Estetis digunakan untuk melihat sudut pandang dasar estetis yang merupakan elemen desain seperti garis, bentuk, warna, komposisi dengan melihat keseluruhan dari kesatuan karya yang akan dibuat, untuk mempermudah penempatan bentuk motif dan busana sehingga tetap selaras dan seimbang antara bagian depa dan belakang, samping kanan dan kiri, bagian atas dan bawah, selain itu karya tidak memiliki perlawanan warna atau motif antara karya satu dengan karya yang lain.

\section{Metode Penciptaan}

Metode penciptaan adalah cara yang dipakai dalam mengerjakan tugas ahkir ini diantaranya adalah data dilapangan maupun studi lainnya guna mendukung kelancaran proses penciptaan karya seni. Metode penciptaan karya ini mengacu pada teori Sp. Gustami, dalam konteks metodologis, terdapat tiga tahap penciptaan seni kriya yaitu:

1. Tahap eksplorasi, yaitu aktifitas penjelajahan menggali sumber ide, pengumpulan data dan referensi, pengolahan dan analis data, hasil dari penjelajahan atau analisis data dijadikan dasar untuk membuat rancangan atau desain. Tahap ini untuk melihat keindahan yang ada pada mata dari detail warna, tekstur, dan bentuk untuk dijadikan sumber ide pembuatan motif dan penerapan pada busana yang berbentuk rancangan karya atau desain.

2. Tahap perancangan, yaitu mengantarkan hasil dari penjelajahan atau analisa data kedalam berbagai alternatif desain (sketsa) untuk kemudian ditentukan rancangan atau sketsa terpilih, untuk dijadikan acuan dalam pembuatan rancangan final gambar teknik, dan rancangan final ini berupa proyeksi, potongan, detail, dan perspektif yang sebagai acuan dalam proses perwujudan karya.

3. Tahap perwujudan, yaitu mewujudkan rancangan terpilih atau final menjadi model prototype sampai ditemukan kesempurnaan karya sesuai dengan desain atau ide, tahap untuk mewujudkan karya setelah melalui tahap eksplorasi dan perancangan sehingga akan lebih mudah dalam menyelesaikan proses pembuatan. Setelah hasil sempurna yaitu detail motif dan busana maka diteruskan dengan pembuatan karya yang sesungguhnya.

\section{Tinjauan Pustaka}

\section{Mata}

Mata merupakan bagian tubuh yang sangat berperan penting bagi manusia. Dan ciri-ciri mata yaitu berbentuk bulat, berwarna putih dengan bundaran hitam ditengahnya.

\section{a. Fungsi}

Mata berfungsi untuk memandang hal-hal yang positif, karena mata merupakan anugerah yang paling besar bagi manusia. Dengan mata kita dapat memahami arti kehidupan dengan memandang keindahan alam yang tuhan ciptakan, kita dapat melihat keindahan langit berupa pelangi, meteor, planet-planet, matahari, bulan, bintang serta keteraturannya, keindahan laut dengan deburan ombaknya, keindahan gunung, pohon, binatang dsb. Dengan mata orang dapat melangkah kearah yang benar dan orang bisa memilih jalan mana yang akan ia tempuh serta melangkah dari jalan yang salah dan sesat menuju jalan yang telah digariskan oleh Tuhan. Karena mata selalu berhubungan erat dengan hati dan fikiran, jika hati berkehendak dan fikiranpun jernih maka mata akan melangkah sesuai gerak hati dan fikiran. Dan jika keduanya berlawanan maka mata akan bingung untuk melangkah, mata akan selalu berputar dalam kebingungan. Matapun mempunyai hak untuk istirahat dari aktifitasnya, karena fungsi terbesar mata adalah ketika mata terbangun ia mulai merancang aktifitas kesehariannya, mulai kegiatan dirumah, dikantor, disekolah, cabang olahraga, dsb. Maka sangat penting menjaga kesehatan mata demi menatap hari esok yang lebih cerah.

\section{b. Relasi}

Dalam sisi kehidupan kita tidak bisa lepas dari intaian dan incaran mata. Kita tidur, diam, lari, jalan, sakit, bahkan ketika meninggalpun puluhan 
mata mengintai dan mengamati kita. Maka jadilah mata-mata dalam hidup kita. Walau bagaimanapun mata tidak selalu untuk kebaikan dan keburukan.

Karena kedudukan mata sebagai pengintai, pengamat, pengawas, dan pengincar. Dan mata dalam makna sufi adalah muraqabah, muhasabah, musyahadah, dan mukasyafah. Seorang politisi dia sangatlah rentan dengan korupsi, ia akan berniat jahat ketika matanya salah dalam memandang, ia tidak lagi peduli terhadap kepentingan rakyat, ia hanya berfikir agar bagaimana caranya beribu-ribu mata menatapnya, mengaguminya, serta memujinya, ia tidak lagi memikirkan bagaimana matanya yang dulu masih menatap kesengsaraan yang mestinya sebagai pelajaran hidup agar terhindar dari sikap sombong, angkuh, serta rakus.

\section{c. Sejumlah Isyarat Mata}

Kontak mata terikat dalam norma budaya. Dalam budaya Eropa atau Amerika, kontak mata ketika berbicara itu penting. Terlalu sedikit kontak mata dilakukan, bisa menyebabkan seseorang merasa diabaikan dan tak dihargai. Berbeda dengan orang Asia. Orang Asia umumnya lebih nyaman dengan frekuensi kontak mata yang rendah. Bagi orang Asia, tingkat kontak mata yang tinggi menyebabkan rasa malu. Di Jawa, saya sering melihat orang-orang memejamkan matanya untuk meningkatkan konsentrasi untuk mendengar secara serius yang mungkin akan dianggap tak sopan sama sekali dalam budaya Eropa atau Amerika. Secara gender, perempuan umumnya melakukan kontak mata lebih lama dibandingkan dengan laki-laki. Karena perempuan memiliki kecenderungan menampakkan emosi dibanding laki-laki. Sebagian wanita senang mencari umpan balik positif dibandingkan dengan laki-laki.

Mata juga dapat berbicara, memberi sejumlah paket isyarat kepada orang dan mengirimkan sinyal perasaan. Bila laki-laki atau perempuan terangsang melihat sesuatu, maka pupil akan membesar. Dan pembesaran pupil juga dapat memberi petunjuk ketertarikan, minat dan emosi yang ada didalam hati. Namun apabila reaksi orang itu negatif, pupil biasanya ukurannya mengecil. Pandangan mata bisa memberikan petunjuk kedekatan secara psikologis. Tatapan mata kasih sayang seorang ibu kepada anaknya sangat lembut. Demikian pula tatapan suami-istri yang saling mencinta, tatapannya hangat dan syahdu. Pandangan mata mereka lebih kerap diselingi dengan sentuhan yang meningkatkan kedekatan psikologis, dan membangkitkan atmosfir rasa aman dan damai dalam keluarga.

Sejumlah petunjuk kebohongan pun dapat dilihat dari matanya. Orang yang berbohong menurut penelitian Mehrabian, bola matanya sering melihat keatas. Ia berbicara lebih lambat dan membuat banyak kesalahan dalam berbicara. Pembohong sering menggunakan sedikit kata-kata dan itu pun tidak mendalam. Pembohong berhenti (pause) lebih lama sebelum menjawab pertanyaan. Beberapa gerak gerik yang menunjukkan kebohongan menurut Morris adalah menutup mulut (tangan dimulut dan ibu jari dipipi), memegang hidung dan menggosokkan mata.

\section{d. Etika Komunikasi mata}

Etika berasal dari bahasa Yunani kuno, yakni ethos dalam bentuk tunggal yang mempunyai banyak arti: tempat tinggal yang biasa: padang rumput, kandang, habitat: kebiasaan, adat: akhlak, watak: perasaan, sikap, cara berpikir. Dalam bentuk jamak (ta etha) artinya adalah: adat kebiasaan. (K Bertens. 2013: 4) Karena mata adalah sejumlah paket isyarat non verbal yang sangat besar dampaknya untuk orang lain. Karena itu kita perlu menjaganya agar tatapan mata kita tak sampai menyakiti perasaan orang maupun menggagalkan rezeki yang semestinya kita peroleh.

Pandangan mata yang tajam sebaiknya dihindari, karena melahirkan ketidaknyamanan. Memandang dengan cara yang soft akan lebih mencairkan suasana dan membuat urat syaraf lebih rileks, sehingga lebih mudah untuk berkomunikasi.

\section{Busana Modern}

Desain merupakan pola perancangan yang dijadikan dasar pembuatan suatu benda yang akan diciptakan. Dalam Ensiklopedi Nasional Indonesia desain adalah kata lain dari designare yang menggambarkan secara umum pengertian proses pembuatan sketsa atau rancangan pada suatu karya seni (Setiawan Puspita, 2004: 309). Busana dengan teknik kombinasi adalah suatu teknik pembuatan pola yang mengombinasikan pola draping dengan pola kontruksi sehingga menghasilkan pola sempurna. Pola draping adalah pola yang dibuat langsung pada tubuh manusia. Sementara pola konstruksi merupakan pola dasar sistem paris (Pujiwati dan Setyaningsih, 2009:16).

Gaya busana casual bisa diartikan sebagai gaya busana yang santai, informal dan nyaman, busana yang bisa digunakan sehari-hari dan membuat kalian bergerak bebas dan nyaman digunakan. Busana casual ini sangat cocok digunakan di negara dengan iklim tropis seperti Indonesia, dimana di sini terdapat musim panas yang panjang dan iklim udara cenderung panas.

Busana casual identik dengan gaya berbusana anak muda dan mahasiswa, tapi sebenarnya gaya busana santai cocok digunakan oleh siapapun dari segala usia yang memiliki jiwa yang muda dan bebas. Walaupun begitu kita tetap harus memperhatikan gaya busana casual yang pas dan sesuai dengan kondisi pekerjaan dan tempat, Jangan sampai busana yang anda kenakan terlalu santai hingga dianggap tidak sesuai dan tidak menghargai orang sekitar. 
Seiring berkembangnya zaman, kreasinya tidak hanya terpaku dengan kancing bukaan depan dan kain tetapi telah jauh berkembang menjadi busana yang memiliki arti luas dalam penggunaannya (Dimas Singgih Utomo, 2014:7). Sehingga busana casual ini di buat sesuai mode yang berkembang sekarang dan menjadikannya busana modern.

\section{a. Fungsi Busana}

Busana secara umum, fungsinya untuk melindungi tubuh manusia dari cuaca, meskipun bagian tubuh yang dilindungi berbeda dari satu budaya ke budaya lainnya. Material yang digunakan juga amat beragam karena biasanya bersumber pada kondisi alam sekitarnya. Dalam banyak budaya, busana juga ekspresi seni dan keindahan. Oleh karenanya, tidak sekadar memenuhi kebutuhan dasar manusia, tetapi juga menjadi salah satu wadah ekspresi budaya," jelas Irwan M. Hidayana, antropolog dari Fakultas Ilmu Sosial dan Ilmu Politik, Universitas Indonesia .

Busana memiliki beragam makna eksplisit dan implisit. Busana adalah wujud imitasi dari tubuh sosial seseorang, sehingga batasan kenyamanan setiap personal menjadi berbedabeda. Sehelai pakaian mampu menggambarkan suatu struktur kehidupan sosial, ideologi, sejarah, golongan, komunitas, dan juga identitas. Ideologi agama pada pakaian, mengenai permasalahan moral dan etika, merupakan aturan atau hukum mengenai bagaimana berpakaian sesuai dengan kondisi ruang, tempat, dan waktu, yang perlu dipahami dan dilaksanakan. Seharusnya kebebasan dalam kreasi berbusana tidak melupakan hubungan busana dengan lingkungan sosial disekitarnya. Karena busana sebagai kebutuhan pokok, masuk pada wilayah publik, sehingga pertimbangan kelayakan sosial masih diperlukan. Pada akhirnya, busana tetaplah bagian benda mati, konstruksi sosial didalamnya, yang menjadikan pakaian sebagai produk seni yang bermakna ganda.

b. Busana

Busana adalah mesin komunikasi (Umberto Eco: 1976). Busana memiliki fungsi komunikasi, lewat busana manusia bisa memperkenalkan dirinya sekaligus menyampaikan pesan kepada orang di luar dirinya. Kebutuhan manusia atas medium untuk berkomunikasi adalah kebutuhan pokok, karena komunikasi merupakan bagian terpenting dalam dinamika kehidupan sosial kemasyarakatan. Bagi orang Jawa, mengkomunikasikan ka-Jawa-annya bisa mereka sampaikan dengan mengenakan kebaya untuk perempuan, sedangkan untuk para laki-laki mengenakan surjan, blangkon misal. Bagi masyarakat di Papua, mengenakan Koteka merupakan cara mereka menyampaikan ciri khas kebudayaan mereka, begitu pula dengan busana Ulos yang dikenakan oleh masyarakat suku Batak
Karo yang mereka percayai sebagai jimat karena mempunyai daya magis, busana "Pesa'an" Madura yang hanya berbentuk kaos merah bergaris merah putih dan celana longgar dan wanitanya mengenakan kebaya dan seterusnya. Dalam sekup Indonesia kita bisa mengenakan "batik" sebagai identitas ke-Indonesia-an kita. Terlebih lagi bahwa batik sudah diakui oleh dunia sebagai salah satu pakaian yang menjadi identitas Indonesia.

Dalam hal ini busana merupakan ekspresi identitas pribadi, oleh karena itu secara sadara atau tidak ketika "memilih busana, baik di toko maupun di rumah berarti mendefinisikan dan menggambarkan diri kita sendiri" (Lurie, 1992:5). Tentu saja ini bukanlah persoalan orang yang terpaksa mengenakan seragam, karena tipe busana semacam itu diperuntukkan untuk mengurangi individualitas guna memaksakan identitas kolektif. Untuk contoh itu kita bisa melihat di kalangan pejabat yang gemar mengenakan kemeja safari atau baju batik Korpri. Ini tidak hanya membangkitkan esprit de corps di kalangan mereka, tetapi juga menyiratkan berhasilnya ideologi penyeragaman selera berbusana dan pembentukan identitas kolektif dari kelas sosial birokrat yang merasa di atas lapis atas strata sosial. Di sini, gaya busana menjadi satu indikator status sosial yang jelas. Dengan cara demikian, terbukti kelompok kepentingan berhasil menggunakan kode-kode busana untuk menciptakan penampilan yang kuat control negara, bangsa, dan solidaritas kelompok. (Nordholt dalam Barnard, 2011)

\section{PEMBAHASAN}

\section{Proses Penciptaan}

\section{Data Acuan}

Data acuan merupakan faktor penting dalam proses penciptaan karya, data gambar maupun tulisan membantu bereksplorasi mengasah kreativitas dalam berkarya seni. Data acuan juga dapat memberikan batasan yang jelas mengenai konsep karya yang diciptakan, data yang terkumpul memberikan ruang dalam proses penciptaan karya, data acuan didapatkan penulis dengan melakukan kegiatan studi pustaka, dan observasi dilakukan pada perkembangan busana dan mata.

Kelengkapan data yang didapat dari studi pustaka, dan obesrvasi pada perkembangan busana modern maupun bentuk mata dapat membantu proses penciptaan karya, dengan demikian proses penciptaan karya benar-benar bisa mengambil berbagi bentuk dari mata yang kemudian dapat diaplikasikan dalam karya busana modern.

\section{Rancangan karya}



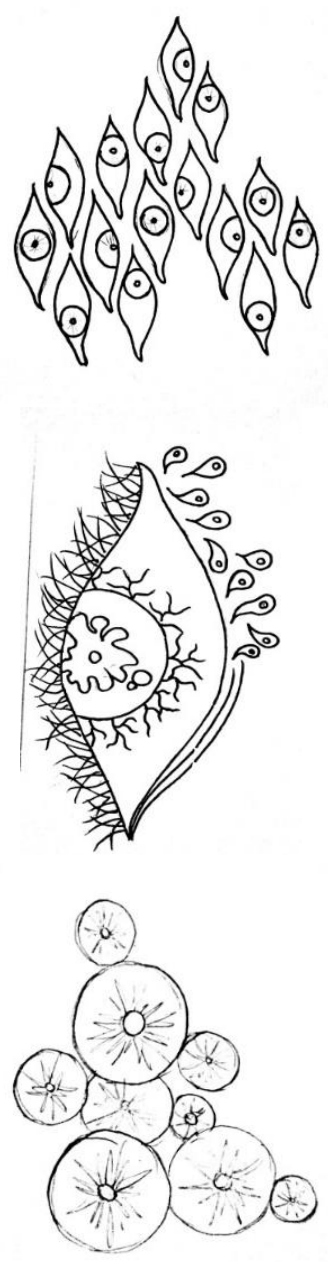

Gambar 1. Sketsa detai motif pada busana

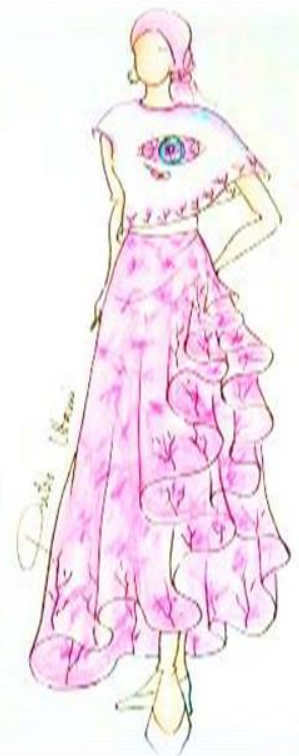

Gambar 2. Sketsa busana I

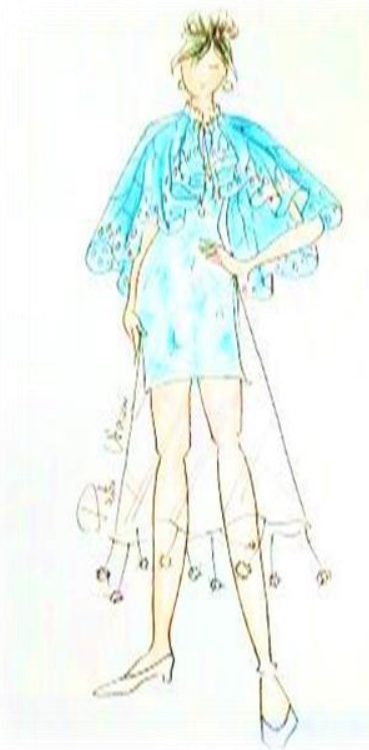

Gambar 3. Sketsa busana II

3. Bahan dan teknik

Kain yang dapat menyerap warna yaitukain yang mengandung serat katun beberapa bahan yanga digunakan pada penciptaan karya adalah kain primisima, kain dolby, dan kain paris. Penggunaan pewarna kain untuk menghasilkan warna yang sesuai menggunakan pewarna kimia yaitu pewarna remasol pengunci warnanya menggunakan waterglas. Untuk teknik pengerjaannya menggunakan batik tulis, sulam tapis, jahit, dan pemasangan manik-manik.

4. Tahap perwujudan

a. Pemindahan pola dan motif pada kain

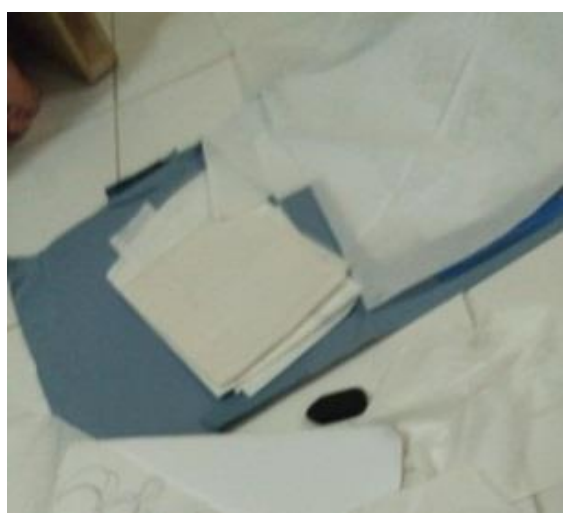

Gambar 4. Proses pembatikan Fotografer : Resmiyanti

Tahap awal ini untuk memudahkan proses pembatikan dan penjahitan, yaitu memindahkan pola busana dan motif yang akan diterapkan pada karya.

b. Pembatikan 


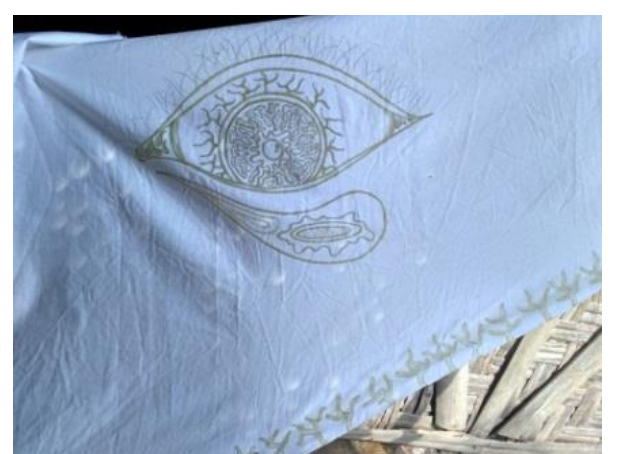

Gambar 5. Proses pembatikan Fotografer : Resmiyanti

Proses pembatikan adalah proses penutupan kain untuk perintang warna masuk menggunakan canting dan malam batik yang dipanaskan, malam dicanting sesuai motif yang sudah dibuat pada tahap pemindahan pola motif dan busana.

\section{c. Pewarnaan}

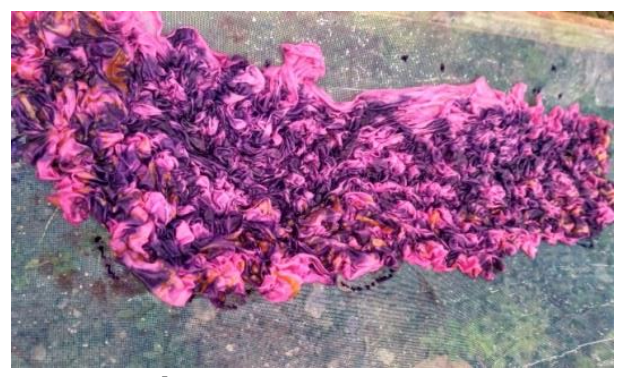

Gambar 6. Proses pewarnaan

Fotografer : Putri Utami

Pewarnaan menggunakan pewarna remasol, teknik yang digunakan ada dua yaitu pencelupan dan colet.

\section{d. Penjahitan}

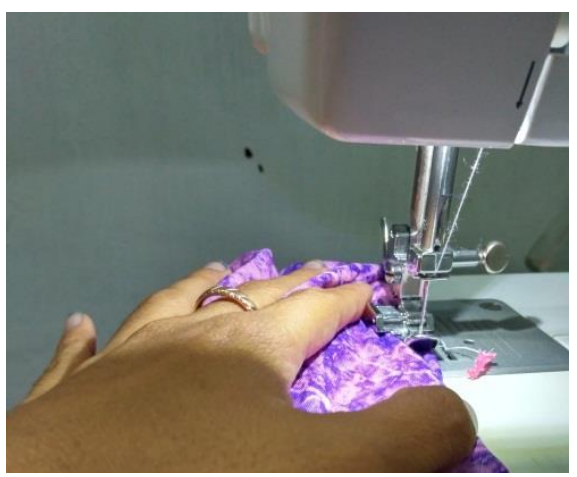

Gambar 7. Proses penjahitan Fotografer : Fidya Anisa

Proses jahit adalah proses penggabungan antara pola satu dengan pola yang lain, penggabungan kain dilakukan sesuai dengan desain yang sudah dibuat, sehingga hasilnya bisa sesuai dengan desain.

\section{e. Finishing}

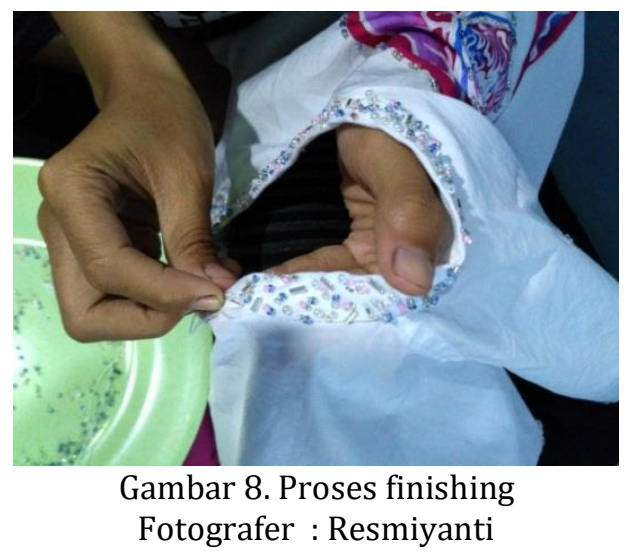

finshing ini adalah proses terahir dalam pengerjaan busana, pada tahap ini tahap pemasangan manik-manik seperti payet, kristal. Selain itu menggunakan sulam tapis. Finishing karya menggunakan beberapa teknik yang ada didalam kriya tekstilsehingga menjadi satu kesatuan.

\section{Hasil Penciptaan Karya}

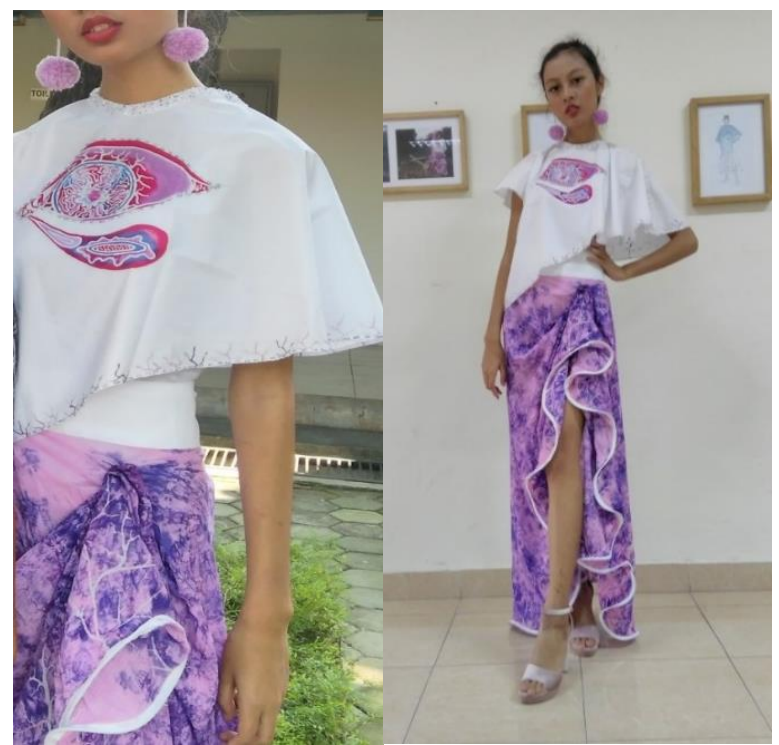

Gambar 9. Hasil karya I

Fotografer: Awaludin GD

$\begin{array}{ll}\text { Judul Karya } & \text { :Mainkanlah } \\ \text { Bahan } & \text { :Kain dolby, Paris, Primisima } \\ \text { Warna } & \text { :Remasol } \\ \text { Teknik } & : \text { Batik Tulis } \\ \text { Tahun } & : 2018\end{array}$

Deskripsi : Memberanikan diri dalam mengarungi kehidupan adalah berani mengambil sikap dalam berbagai hal. Memainkan peran seturut dengan 
kapasitas kemampuan yang dimiliki merupakan bagian dari keberanian. Orang tidak akan berani memainkan kehidupan tanpa berani mengambil resiko dalam kehidupan itu sendiri. Dunia adalah tempat bermain-main, begitulah yang diceritakan oleh kitab suci, maka memberanikan diri memainkan peran untuk bermain-main di kehidupan adalah kehidupan yang sesungguhnya.

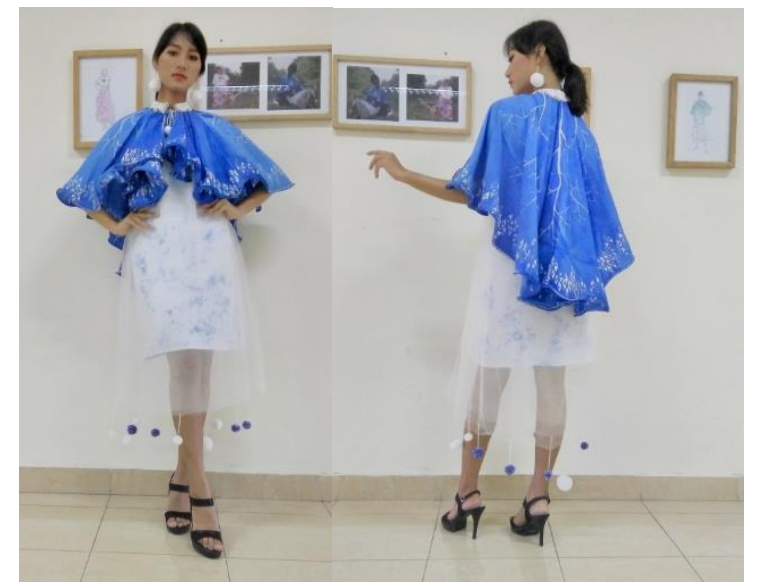

Gambar 10. Hasil karya II

Fotografer : Awaludin GD

$\begin{array}{ll}\text { Judul Karya } & \text { :Tenanglah } \\ \text { Bahan } & : \text { Kain dolby, paris, tile } \\ \text { Warna } & : \text { Remasol } \\ \text { Teknik } & : \text { batik tulis, sulam tapis, makram } \\ \text { Tahun } & : 2018\end{array}$

Deskripsi: Dalam kehidupan manusia kerap dihadapkan dengan berbagai macam cobaan. Baik berupa cobaan yang berupa nikmat maupun cobaan yang berupa kesengsaraan. Maka dari itu, manusia harus memiliki sikap yang tenang dalam menghadapi dua bentuk cobaan tersebut, karena hanya dengan ketenangan, nikmat dan kesengsaraan mampu disikapi secara bijak.

Terlebih lagi pada saat ini, kehidupan berbangsa-bernegara dan beragama di Indonesia sedang diuji oleh dua hal tersebut, yaitu: kenikmatan dan kesengsaraan.

\section{KESIMPULAN}

Karya seni ini diciptakan untuk mendapatkan kepuasan batin, tidak hanya diekspresikan dalam bentuk visual namun mengandung makna dan filosofi. Ide, konsep dan teknik yang seimbang menghasilkan suatu karya yang tidak hanya indah namun berkarakter serta mengandung makna yang mendalam. Karya berjudul "Mata Sebagai Sumber Ide Penciptaan Motif Dalam Busana Modern", memvisualkan Mata yang memiliki karakter dan pengertian tersendiri dalam aspek kehidupan. Penggunaan motif mata memiliki makna tersendiri. Di tambah penerapan pada busana moderen yang akan memberikan makna yang sangat mendalam. Selain itu, penggunaan warna-warna yang berkesan halus dan tidak terlalu mencolok menambah kesan mendalam dan berbagai macam makna yang terkandung dapat nampak dan cocok secara makna maupun visual.

\section{DAFTAR PUSTAKA}

Barnard, Malcolm. (2011). Fashion Sebagai Komunikasi: Cara mengkomunikasikan identitas, sosial, seksual, kelas dan gender, Jalasutera: Yogyakarta.

Bertens, K. (2013). Etika, Kanisius. Yogyakarta.

Djelantik A.A.M., (2001). Estetika Sebuah Pengantar, Bandung: Masyarakat Seni Pertunjukan Indonesia, kuBuku

Gustami SP., (2007). Butir-Butir Mutiara Estetika Timur: Ide Dasar Penciptaan Seni Kriya Indonesia., Yogyakarta: Prasista.

Gustami SP, Nukilan. (2008) Seni Ornamen Indonesia. Jurusan Kriya Fakultas Seni Rupa ISI. Yogyakarta

Hadiatmodji, Supardi, (1990). Sejarah Seni Rupa Eropa, Semarang : IKIP SEMARANG PRESS.

Hana, Humaira, (2013). Makalah Penelitian Agama Kebudayaan dan Seni Islam, Jakarta.

Herarti, Toeti, (1984). Aku Dalam Budaya, Suatu Telaah Filsafat Mengenai Hubungan SubjekObjek, Pustaka Jaya. Bandung.

Sunardi, ST, (2012). Vodka dan Birahi Seorang Nabi: Esei-esei Seni dan Estetika. Yogyakarta: Jalasutera.

Setiawati, Puspita. (2004) Kupas Tuntas Teknik Proses Pembatik, Yogyakarta: Absolut.

Majalah Fashion Pro, (2009), Jakarta: P.T.Indigo Red Promedia 
Putri Utami Mukti / IKONIK : Jurnal Seni dan Desain, Vol. 2, No.1, Januari 2020, 1-8

( Halaman ini sengaja dikosongkan) 